\title{
Comparison of V-Y Flap and Limberg Flap Methods in Pilonidal Sinus Surgery
}

\section{Pilonidal Sinüs Cerrahisinde V-Y Flep ile Limberg Flep Yöntemlerinin Karşılaştırılması}

\author{
(1) Ramazan Sarı1, (1) Soner Akbaba2, () Rıza Haldun Gündoğdu22, (1) Mustafa Ömer Yazıcıoğlu22 \\ ${ }^{1}$ Muş Malazgirt State Hospital, Clinic of General Surgery, Muş, Turkey \\ 2Ankara Atatürk Training and Research Hospital, Clinic of General Surgery, Ankara, Turkey
}

\section{IIIIIII| ABSTRACT}

\begin{abstract}
Aim: The aim of this study was to compare the advantages of V-Y flap and Limberg flap techniques in the surgical management of complicated pilonidal sinus disease requiring extensive excision, and to review the superiorities of each other in the light of the literature.

Method: The study included 100 patients who were hospitalized with the diagnosis of pilonidal sinus disease and who were planned to undergo flap reconstruction due to the diameter of the defect. Patients were randomly divided into two groups as A and B. Fifty patients in group A underwent V-Y flap and 50 patients in group B underwent Limberg flap. Both groups were prospectively followed-up in terms of complications, recovery times, workforce losses, patient satisfaction and 2-year recurrence rates, and the findings were compared statistically.

Results: Demographic characteristics, complaints and clinical findings of both groups were similar. Although postoperative wound infection rates were similar ( $26 \%$ vs. $28 \%$; p $>0.05$ ), wound dehiscence was more common in the Limberg group ( $36 \%$ vs. $26 \%$; p $<0.05$ ). The wound healing process and workforce losses were longer in the Limberg flap group, but the differences were not statistically significant. There were no differences between the groups in terms of patient satisfaction and recurrence in the 2-year follow-up period.

Conclusion: The long-term recurrence rates of V-Y flap and Limberg flap techniques are similar. Wound dehiscence is significantly less in V-Y flap technique. According to the results of this study, V-Y flap method following extensive tissue loss due to excision can be considered as a good alternative.
\end{abstract}

Keywords: Pilonidal sinus, Limberg flap, V-Y flap

\section{||||||||||| ÖZ}

Amaç: Komplike, geniş eksizyon yapılmasını gerektirecek pilonidal sinüs hastalığının cerrahi tedavisinde popüleritesini koruyan iki yöntem olan V-Y ile Limberg flep tekniklerini karşılaştırılarak, birbirine olan üstünlüklerinin literatür ışı̆̆ında gözden geçirilmesi amacıyla bir çalışma planlandı. Yöntem: Çalışmaya pilonidal sinüs hastalığı tanısı ile yatırılan ve oluşacak defekt genişliği sebebiyle flep uygulanması planlanan 100 hasta dahil edildi. Randomize olarak 2 gruba ayrılan hastalardan A grubundaki 50 hastaya V-Y flep, B grubundaki 50 hastaya ise Limberg flep uygulandı. Her iki grup gelişen komplikasyonlar, iyileşme süreleri, iş gücü kayıpları, hasta memnuniyetleri ve 2 yıllık nüks oranları açısından prospektif olarak takip edildi ve elde edilen bulgular istatistiksel olarak karşılaştırıldı.

Bulgular: Her iki grubun demografik özellikleri, yakınmaları ve klinik bulguları benzerdi. Postoperatif yara enfeksiyonu oranları yakın olmakla birlikte (\%26, \%28; p>0,005) yara ayrışması Limberg grubunda daha fazla görüldü $(\% 26, \% 36 ; p<0,005)$. Yara iyileşme süreci, iş gücü kayıpları Limberg flep grubunda daha uzun olmakla birlikte sonuçlar istatistiksel açıdan anlamlı değildi. Hasta memnuniyetleri ve takip edilen 2 yıllık dönemdeki nüksler açısından gruplar arasında fark yoktu.

Sonuç: V-Y flep ve Limberg flep tekniklerinin uzun dönem nüks oranları yakındır. Yara açılması V-Y flep tekniğinde anlamlı olarak daha azdır. Bu çalışmanın sonuçlarına göre, geniş doku kaybına neden olan eksizyon sonrası V-Y flep yöntemi iyi bir alternatif olarak kabul edilebilir.

Anahtar Kelimeler: Pilonidal sinüs, Limberg flep, V-Y flep

Presented in: The abstract of this study was presented as an electronic poster (EPS-0517) at the $21^{\text {st }}$ National Surgery Congress held in Antalya between 11-15 April 2018 and its sample was added.

Address for Correspondence/Yazışma Adresi: Ramazan Sarı MD,

Muş Malazgirt State Hospital, Clinic of General Surgery, Muş, Turkey

Phone: +90 5056294662 E-mail: sariramazan71@gmail.com ORCID ID: orcid.org/0000-0003-3492-9953

Received/Geliş Tarihi: 24.09.2018 Accepted/Kabul Tarihi: 19.11.2018

${ }^{\circ}$ Copyright 2019 by Turkish Society of Colon and Rectal Surgery

Turkish Journal of Colorectal Disease published by Galenos Publishing House. 


\section{Introduction}

Pilonidal sinus disease is a subcutaneous tissue disease that is common in the community and that mostly affects young adult patients. The incidence is $26 / 100000$ in the general population and its frequency is higher in young patients and males. ${ }^{1}$ Patients usually present with signs of abscess or sinus with chronic discharge. The treatment of the disease is important because of the painful and frequently recurring symptoms that affect the patient's lifestyle. The ideal treatment should be able to provide conditions such as quick recovery, no need for general anesthesia, outpatient treatment, minimal discomfort, minimal loss of workforce, better patient satisfaction with good cosmetic results, less recurrence and less cost. However, although many conservative and surgical methods have been defined, recurrence rates are still high and the search for the ideal treatment is ongoing. ${ }^{2,3}$

Although the treatment of pilonidal sinus disease in the form of acute abscess is standard (drainage), the treatment of chronic and recurrent cases is not clear. Conservative treatment methods are recommended for simple cases with single orifice and short tracts. Surgical treatment with excision is generally accepted in cases with chronic course, multiple orifices or recurrence; however, the method of closure of the defect is controversial. In particular, there is no clear consensus on the method to be chosen for the closure of the defect in complicated or recurrent cases where the tissue loss is large.

This prospective randomized study aimed to compare popular Limberg flap and V-Y flap techniques in order to add a comment to this subject.

\section{Materials and Methods}

After the approval of the Ethics Committee of Medical Faculty of Yıldırım Beyazıt University, the patients who were admitted to General Surgery Clinic of Ankara Atatürk Training and Research Hospital between February 2012 and 2016 and who would need flap for the defect in the sacrococcygeal region after pilonidal sinus excision were included in the study. Patients who had a systemic disease that could adversely affect wound healing and who refused to participate in the study during the informed consent were excluded. When the power analysis was performed for statistical evaluation, it was calculated that 100 patients would be sufficient. Patients were labeled in groups A and $\mathrm{B}$ according to the order of admission. After excision of the diseased part, V-Y flap was applied to the patients in group A and Limberg flap technique was used in group B. When both groups reached 50 patients, the study was finalized.

Age, gender, duration of complaints, physical examination findings, body mass index, anesthesia method, length of hospital stay, orifice number and length of the sinus tract were recorded. All postoperative data regarding wound infection, wound dehiscence, suture removal day, postoperative loss of sensation, time to return to work, recurrence and its treatment, patient satisfaction and cosmetic concerns were recorded.

The surgical field of all patients was shaved on the operating table just before the operation. Povidone-iodine was used for skin cleansing. All patients underwent antibiotic prophylaxis with $1 \mathrm{~g}$ of cefazolin sodium during anesthesia induction. After the patients were taken to the operating table in the prone jackknife position, the excision area and the area suitable for the flap technique were marked with a pen.

In group $\mathrm{A}$, the tissue was totally excised down to presacral fascia with a rectangular incision including all sinuses and pits until the presacral fascia was visualized. Following hemostasis, a $\mathrm{V}$ shaped incision was used to incise the right gluteal region up to gluteus muscle fascia and the tissue to be used for the flap was mobilized. The obtained fasciacutaneous flap was shifted to the opposite side in Y shape and was sutured to presacral fascia and subcutaneous skin with $1 / 0$ polyglactine sutures. The skin was closed in interrupted 2/0 monofilament polypropylene sutures (Figure 1). A hemovac drain was used in all patients.

In group $\mathrm{B}$, the tissue was totally excised down to presacral fascia with a rhomboid incision including all sinuses and pits. Following hemostasis, the flap from the right gluteal region was raised so that it included skin, subcutaneous fat, and the fascia overlying gluteus maximus, and rotated to cover the defect. Rhomboid was inserted into the defect so that the lower end did not remain in the intergluteal groove. The flap was sutured to presacral fascia and subcutaneous skin with $1 / 0$ polyglactine sutures. The skin was closed in interrupted 2/0 monofilament polypropylene sutures. A hemovac drain was used in all patients (Figure 2).

All surgeries were performed by the same team. The wound was cared with pressure dressings and the drains were preserved until the daily drainage was below $10 \mathrm{~mL}$. The wound infection was defined as presence of symptoms such as erythema, pain, redness, and induration, or surgeon opening the wound or defining the wound as infected, as well as purulent drainage not exceeding the skin and subcutaneous tissue in the wound within 30 days after the surgery. Five days of oral ampicillin + sulbactam treatment was performed in patients with wound infection. Spontaneous dehiscence without any evidence of infection in the first month was defined as wound dehiscence. The sutures of the patients in both groups were removed in our outpatient clinic and the day of removal was recorded in the 
follow-up form. Patients in follow-up were checked in our outpatient clinic at the $6^{\text {th }}, 6^{\text {th }}$ and $24^{\text {th }}$ months. The patients who could not come to the hospital were interviewed by telephone in terms of their time to return to work, operation satisfaction and recurrence, and their results were recorded. While evaluating the patient satisfaction levels, the patients were asked to score with a number between 1 and 5 (highest satisfaction 5 , least satisfaction 1 ).

\section{Statistical Analysis}

SPSS for Windows 20.0 package program (SPSS Inc, Chicago, Illionis, USA) was used for statistical analysis of the data. Continuous variables were expressed as mean \pm standard deviation. Continuous variables were compared using t-test and categorical variables were compared using chi-square test. ANOVA test and post hoc Tukey test were used for the comparison of parametric data between the groups. Kruskal-Wallis and chi-square test were used for comparison of nonparametric values and percentages. A p value of $<0.05$ was considered statistically significant in all tests.

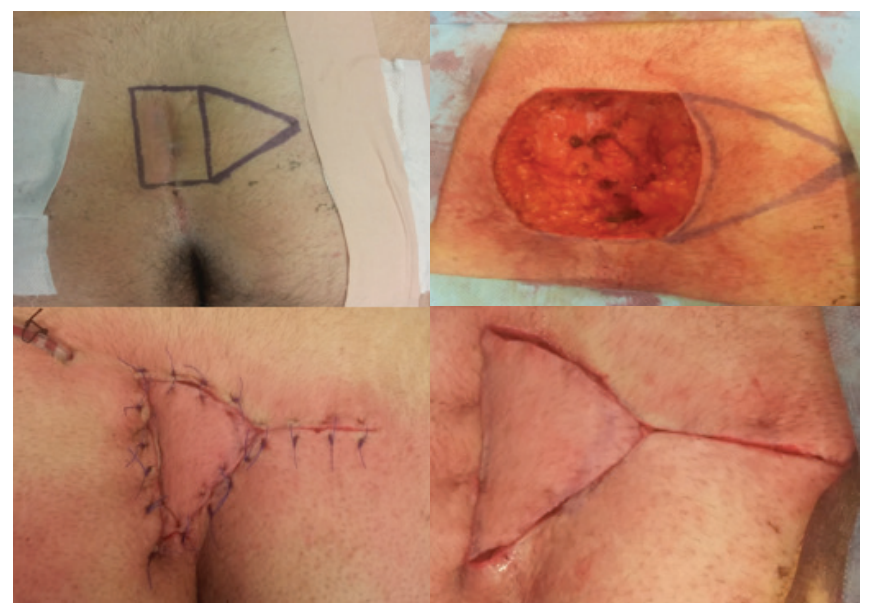

Figure 1. V-Y flap method

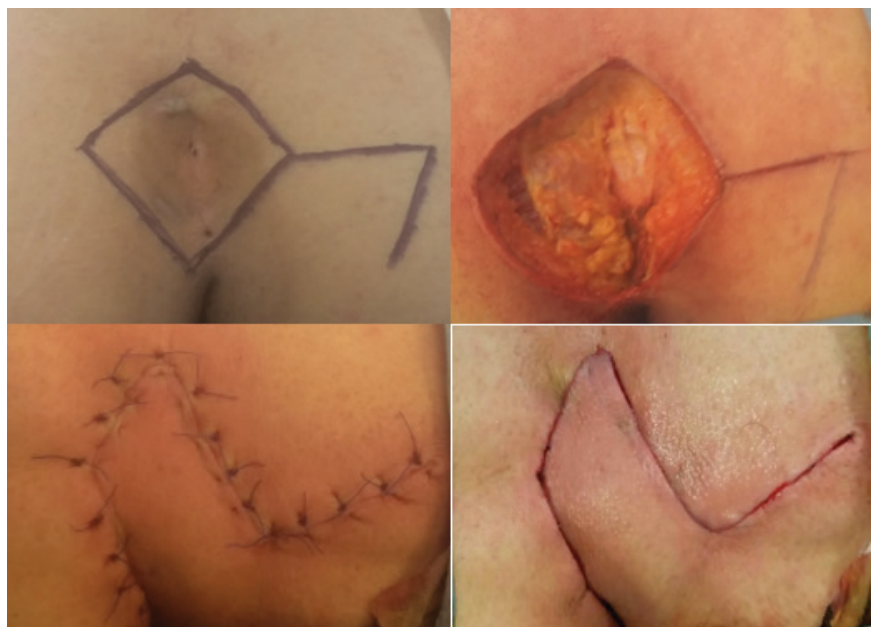

Figure 2. Limberg flap method

\section{Results}

Ninety-three patients were male and seven were female, and the mean age was 26.8 years (range, 15-46). There was no difference between the two groups in terms of demographic characteristics and the anatomical structure of the disease ( $>0.05)$ (Table 1).

Of the patients in group A, the number of patients with previous surgeries were as follows: three had primary repair, one had Limberg flap, one had Karydakis flap, one had marsupialization and five had only drainage. Of five patients with previous surgery in group B, three had primary repair, one had V-Y flap, and one had only drainage. There was no significant difference between the groups in terms of previous surgery data $(\mathrm{p}>0.05)$.

There were no statistically significant differences between the two groups in terms of preoperative symptoms, orifice number, sinus tract length, type of anesthesia used for surgery and length of hospital stay. Complaints of all patients were pain, swelling and discharge in the sacral region. In all cases, there was more than one sinus orifice and there was also sinus orifice outside the midline. In other words, there was a need for an excision that would require a flap in all patients.

There were no differences between the groups in terms of postoperative complications, length of hospital stay, time of suture removal, loss of sensation, and time to return to work (Table 2). Wound infections were found in 13 patients in group A on day 7 (range, 4-13) and in 14 patients in group B on day 7 (range, 3-13). Wound dehiscence was observed on day 6 (range, 3-10) in

Table 1. Characteristics of groups

\begin{tabular}{|c|c|c|c|}
\hline & $\begin{array}{l}\text { V-Y group (A) } \\
(n=50)\end{array}$ & $\begin{array}{l}\text { Limberg group (B) } \\
(\mathrm{n}=50)\end{array}$ & $\mathrm{p}$ \\
\hline Age, years & $26.1(15-45)$ & $27.66(15-46)$ & 0.327 \\
\hline Gender, M/F & $43 / 7$ & $50 / 0$ & 0.075 \\
\hline BMI, kg/m² & $\begin{array}{l}24.93 \\
(20.21-32.41)\end{array}$ & $\begin{array}{l}25.95 \\
(22.49-34.61)\end{array}$ & 0.189 \\
\hline Comorbidities & 0 & 1 & 0.317 \\
\hline Previous surgery & 11 & 5 & 0.103 \\
\hline $\begin{array}{l}\text { Duration of } \\
\text { complaints, } \\
\text { month }\end{array}$ & $18.34(1-96)$ & $17.27(0.5-120)$ & 0.418 \\
\hline $\begin{array}{l}\text { Number of sinus } \\
\text { orifices }\end{array}$ & $3(2-5)$ & $3(2-6)$ & 1.00 \\
\hline Tract length, cm & $3.03(1-7)$ & $2.7(1-7)$ & 0.306 \\
\hline
\end{tabular}

M: Male, F: Female, BMI: Body mass index 
group A and on day 9 (range, 3-14) in group B. While there was no difference between the groups in terms of time of dehiscence, it was seen in more patients in Limberg group (36\% vs. $26 \%$; $\mathrm{p}<0.05$ ).

Recurrence was observed in two patients (mean: 19 months) in group A and in three patients in group B (mean: 11 months) in the first 2 years. Although there was no significant difference between the groups in terms of recurrence, it was observed that recurrences developed earlier in the Limberg group. Contrary to the predicted, there was no difference in recurrence rates between obese patients and non-obese patients, and patients with and without infection ( $p>0.05)$.

Although it was observed that patients in group A were more satisfied with cosmetic results, there was no statistically significant difference between the two groups in terms of overall satisfaction ( $p>0.05)$ (Graphic 1$)$.

Table 2. Postoperative findings

\begin{tabular}{|c|c|c|c|}
\hline & $\begin{array}{l}\text { V-Y group } \\
\text { (A) }\end{array}$ & $\begin{array}{l}\text { Limberg group } \\
\text { (B) }\end{array}$ & $\mathrm{p}$ \\
\hline Wound infection & 13 & 14 & 0.823 \\
\hline Wound dehiscence & 13 & 18 & 0.004 \\
\hline $\begin{array}{l}\text { Length of hospital } \\
\text { stay, day }\end{array}$ & $1.84(1-5)$ & $2.02(1-7)$ & 0.564 \\
\hline Suture removal, day & $17.8(12-30)$ & $18.7(12-30)$ & 0.354 \\
\hline Loss of sensation & 5 & 7 & 0.540 \\
\hline Return to work, day & $27.86(7-62)$ & $27.38(15-60)$ & 0.832 \\
\hline Patient Satisfaction & $4.28(1-5)$ & $4.14(2-5)$ & 0.499 \\
\hline Recurrence & 2 & 3 & 0.648 \\
\hline
\end{tabular}

Evaluation of patient satisfaction in the V-Y group

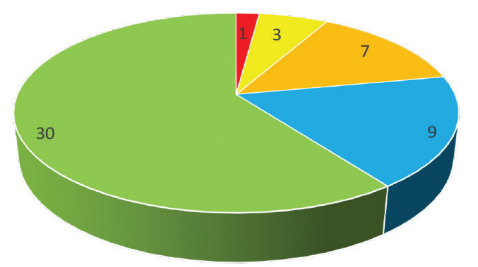

$=1=2=3=4=5$

Evaluation of patient satisfaction in the Limberg group

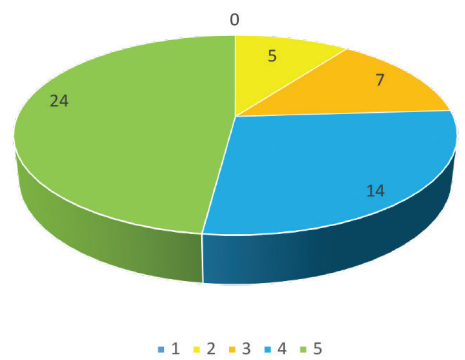

Graphic 1. Evaluation of patient satisfaction

\section{Discussion}

Despite the definition of many methods for the closure of the wound in complicated pilonidal sinus patients treated with surgical excision that leaves a wide tissue defect, there is no consensus on optimal flap technique. The main objective is to ensure that the patient is operated with a technique with a low morbidity and mortality rate, and that he/she returns to work as soon as possible. For this, the complication rate of the procedure should be low, the hospital stay should be short and the recurrence rates should be low. ${ }^{2,4,5}$ As a definite method cannot be established regarding aforementioned features, the V-Y flap and the Limberg flap, which are two popular methods, were compared in this study. ${ }^{6,7}$ There are only three studies in the English literature comparing the V-Y flap and Limberg flap.

There are three basic principles in the surgical treatment of pilonidal sinus disease. These are complete eradication of the sinuses, good closure of the remaining defective area and prevention of recurrences. ${ }^{5,8}$ There is no contradiction in the complete removal of the sinuses, however, the main discussion is on how to close the defect formed. ${ }^{9,10}$ Leaving large defects open or marsupialization are not preferred today due to long recovery time and poor cosmetic results. ${ }^{5,9,10}$ It is difficult to perform flap techniques with more limited dissection such as Karydakis and Bascom without creating tension in large and complicated cases. As is well known, good wound healing can only be achieved by well-fed tissues and minimal tension. Therefore, various flap techniques have been developed and many studies have been published. While many factors such as being primary or recurrence, number of sinuses, defect size, patient preference, and surgeon experience play role in the preferred surgical technique, the most popular flap techniques for cases with large tissue loss are V-Y flap and Limberg flap techniques.

The 2-year recurrence rate of Limberg flap method, which is one of the most frequently used techniques, is reported as $0-6 \%$ in the literature. ${ }^{11}$ A similar recurrence rate was found in this study (6\%). Limberg technique has low recurrence rate and low hospital stay in both primary and recurrent pilonidal sinus cases. However, in some studies in which Limberg flap method has been performed, cosmetic dissatisfaction is a significant disadvantage. ${ }^{12,13}$ In a study in sixty-three patients, $63 \%$ of patients were not satisfied with the cosmetic result. ${ }^{13}$

V-Y flap technique was first used by Khatri et al., ${ }^{6}$ in 1994 in five patients and it is preferred in recurrent cases. The researchers argued that $\mathrm{V}$-Y flap technique provided a better wound healing due to lesser tension, lesser postoperative seroma and dead space rates as a result of limited dissection and mobilization compared to Limberg flap. ${ }^{14,15}$ The 
disadvantage of V-Y flap method reported in the literature seems to be longer operative time and longer hospital stay. ${ }^{16,17}$ Operative times were not compared in our study. However, the length of hospital stay of patients in the V-Y group was similar to that of the Limberg group with a mean of 2 days and was significantly lower than the literature. Similarly, time to return to work of the patients who underwent V-Y flap was similar to the Limberg group and was shorter than the other studies in the literature.

The reported rates for V-Y flap technique was $0-10.2 \%$ for wound site infection, $0-4.6 \%$ for seroma and $0-10.2 \%$ for wound dehiscence. ${ }^{16,17,18}$ The rates we obtained in our study were slightly higher compared to the literature. The reason for this was concluded to be lower sociocultural levels and self-care of our patients and that they did not comply with the post-discharge recommendations.

A controversial subject in the literature is the use of drains. There are publications regarding them as beneficial and there are also studies claiming the opposite. Our general experience in pilonidal sinus surgery is the use of drains. In this study, seroma development is significantly less in all of our patients due to the use of drains. Therefore, in obese patients and those who have large tissue defects, we recommend that the drain is placed and is not removed until the amount of discharge is reduced.

Recurrence rate is one of the most important criteria in the success of surgical procedures. Both techniques have significantly less recurrence rates compared to other methods. The recurrence rate for $\mathrm{V}-\mathrm{Y}$ flap and Limberg flap were $0-11 \%$ and $0-6 \%$, respectively, in the literature. ${ }^{11,17,18}$ In our study, recurrence was detected in only two patients (4\%) in the V-Y flap group and three patients in the Limberg group $(6 \%)$ in a 2 -year period. Although recurrence rate following Limberg procedure is close to the literature, our recurrence rate in the V-Y group is lower.

\section{Conclusion}

In our study, the superiority of V-Y flap technique to Limberg was observed in terms of cosmetic satisfaction and low recurrence rate. Regarding wound dehiscence, V-Y flap results seem to be better with a statistically significant difference. According to the results of this study, V-Y flap technique should be considered as a good choice for the closure of large tissue defects in the surgical treatment of pilonidal sinus disease.

\section{Ethics}

Ethics Committee Approval: The study was approved by the Yıldırım Beyazıt University Faculty of Medicine Ethics Committee (approval number: 20.01.2016/09).
Informed Consent: Written informed consent was obtained from all patients preoperatively.

Peer-review: Externally peer-reviewed.

\section{Authorship Contributions}

Surgical and Medical Practices: S.A., R.S., Concept: R.H.G., Design: R.H.G., R.S., Data Collection or Processing: R.S., S.A., Analysis or Interpretation: M.Ö.Y., Literature Search: R.H.G., R.S., Writing: R.S.

Conflict of Interest: No conflict of interest was declared by the authors.

Financial Disclosure: The authors declared that this study received no financial support.

\section{References}

1. Sondenaa K, Andersen E, Nesvik I, Soreide JA. Patient characteristics and symptoms in chronic pilonidal sinus disease. Int J Colorectal Dis 1995; 10:39-42.

2. Kallis MP, Maloney C, Lipskar AM. Management of pilonidal disease. Curr Opin Pediatr 2018;30:411-416.

3. Johnson EK. Expert Commentary on Pilonidal Disease: Management and Definitive Treatment. Dis Colon Rectum 2018;61:777-779.

4. Humphries AE, Duncan JE. Evaluation and management of pilonidal disease. Surg Clin North Am 2010;90:113-124.

5. De Parades V, Bouchard D, Janier M, Berger A. Pilonidal sinus disease. J Visc Surg 2013;150:237-247.

6. Khatri VP, Espinosa MH, Amin AK. Management of recurrent pilonidal sinus by simple V-Y fasciocutaneous flap. Dis Colon Rectum 1994;37:12321235.

7. Ersoy E, Devay AO, Aktimur R, Doganay B, Ozdogan M, Gündoğdu RH. Comparison of the short-term results after Limberg and Karydakis procedures for pilonidal disease: randomized prospective analysis of 100 patients. Colorectal Dis 2009;11:705-710.

8. Shabbir J, Chaudhary N.N, Britton D.C. Management of sacrococcygeal pilonidal sinus disease: a snopshot of current practice. Int J Colorectal Dis 2011;26:1619-1620.

9. Segre D, Pozzo M, Perinotti R, Roche B. Italian Society of Colorectal Surgery. The treatment of pilonidal disease: guidelines of the Italian Society of Colorectal Surgery (SICCR). Tech Coloproctol 2015;19:607-613.

10. Iesalnieks I, Ommer A, Petersen S, Doll D, Herold A. German national guideline on the management of pilonidal disease. Langenbecks Arch Surg 2016;401:599-609.

11. Stauffer VK, Luedi MM, Kauf P, Schmid M, Diekmann M, Wieferich K, et al. Common surgical procedures in pilonidal sinus disease: A metaanalysis, merged data analysis, and comprehensive study on recurrence. Sci Rep 2018;15;8:3058.

12. Bozkurt MK, Tezel E. Management of pilonidal sinüs with Limberg flap. Dis Colon Rektum 1998;41:775-777.

13. Eryllmaz R, Sahin M, Alimoglu O, Dasran F. Surgical treatment of sacrococcygeal pilonidal sinus with the Limberg transposition flap. Surgery 2003:134:745-749.

14. Schoeller T, Wechselberger G, Otto A, Papp C. Defnite surgical treatment of complicated recurrent pilonidal disease with a modifed fasciocutaneous V-Y advancement flap. Surgery 1997;121:258-263. 
15. Sahasrabudhe P, Panse N, Waghmare C, Waykole P. V-Y advancement flap technique in resurfacing postexcisional defect in cases with pilonidal sinus disease-study of 25 cases. Indian J Surg 2012;74:364-370.

16. Berkem H, Topaloglu S, Ozel H, Avsar FM, Yildiz Y, Yüksel BC, et al. V-Y advancement flap closures for complicated pilonidal sinus disease. Int J Colorectal Dis 2005;20:343-348.
17. Öz B, Akcan A, Emek E, Akyüz M, Sözüer E, Akylldız H, et al. A comparison of surgical outcome of fasciocutaneous V-Y advancement flap and Limberg transposition flap for recurrent sacrococcygeal pilonidal sinus disease. Asian J Surg 2017;40:197-202.

18. Altintoprak F, Dikicier E, Arslan Y, Ozkececi T, Akbulut G, Dilek ON. Comparision of the Limberg flap with the V-Y flap technique in the treatment of pilonidal disease. J Korean Surg Soc 2013;85:63-67. 